\title{
Leaching behavior and ecotoxicological effects of different game shot materials in freshwater
}

\author{
Julian Fäth ${ }^{1, a}$, Mona Feiner ${ }^{2, a}$, Sebastian Beggel ${ }^{2}$, Jürgen Geist ${ }^{2, *}$ and Axel Göttlein ${ }^{1}$ \\ 1 Technical University of Munich, School of Life Sciences, Professorship of Forest Nutrition and Water Resources, Hans-Carl-von- \\ Carlowitz-Platz 2, 85354 Freising, Germany \\ 2 Technical University of Munich, School of Life Sciences, Chair of Aquatic Systems Biology, Mühlenweg 22, 85354 Freising, Germany
}

\begin{abstract}
Lead-based game shot used in hunting near waters is considered a main reason for leadpoisoning of waterfowl and aquatic organisms, prompting discussion about alternatives. This study provides a first comparison of the leaching behavior and resulting ecotoxicological impacts of shot exposed to freshwater, comprising lead-based and alternative shots containing bismuth, copper, steel, tungsten, and zinc. Ecotoxicological effect assessment was based on the acute Daphnia magna $48 \mathrm{~h}$ toxicity test according to the EN ISO 6341:2012 guideline. Strong leaching of copper (up to $4.22 \mu \mathrm{mol} / \mathrm{L}$ ) and zinc (up to $41.12 \mu \mathrm{mol} / \mathrm{L}$ ) from three types of alternative game shot caused significantly increased immobilization rates of up to $100 \%$. In contrast, even the highest leaching of lead did not significantly impair Daphnia mobility. Highest concentrations of dissolved metal ions only matched the declared main components of the respective shots in 3 out of 9 cases. These results demonstrate that metal release from alternative game shot is an underestimated ecotoxicological risk, particularly since release of copper and zinc from alternative shots was demonstrated to be more hazardous for aquatic biota than conventional lead shot. There is an urgent need of managing the use of shot ammunition near waterbodies based on realistic ecotoxicological risk assessments.
\end{abstract}

Keywords: heavy metal / water pollution / ammunition / lead / Daphnia magna

Résumé - Comportement de lixiviation et effets écotoxicologiques des différents matériaux de la grenaille de tir en eau douce. La grenaille de plomb utilisée dans la chasse près des eaux douces est considérée comme une des principales causes de l'empoisonnement par le plomb de la sauvagine et des organismes aquatiques, ce qui suscite la discussion sur les solutions de rechange. Cette étude fournit une première comparaison du comportement de lixiviation et des impacts écotoxicologiques résultants de la grenaille exposée à l'eau douce, comprenant des grenailles à base de plomb et des grenailles alternatives contenant du bismuth, du cuivre, de l'acier, du tungstène et du zinc. L'évaluation des effets écotoxicologiques a été basée sur l'essai de toxicité aiguë Daphnia magna $48 \mathrm{~h}$ selon la norme EN ISO 6341:2012. Une forte lixiviation du cuivre (jusqu' à 4,22 $\mu \mathrm{mol} / \mathrm{L}$ ) et du zinc (jusqu' à $41,12 \mu \mathrm{mol} / \mathrm{L}$ ) provenant de trois types de grenaille de rechange a entraîné une augmentation significative des taux d'immobilisation pouvant atteindre 100 \%. En revanche, même le lessivage le plus élevé du plomb n'a pas réduit de façon significative la mobilité des Daphnies. Les concentrations les plus élevées d'ions métalliques dissous ne correspondaient aux principaux composants déclarés des grenailles respectives que dans 3 cas sur 9. Ces résultats démontrent que le rejet de métaux provenant d'autres grenailles est un risque écotoxicologique sous-estimé, d'autant plus qu'il a été démontré que le rejet de cuivre et de zinc provenant d'autres grenailles est plus dangereux pour le biote aquatique que la grenaille de plomb classique. Il est urgent de gérer l'utilisation des munitions de tir à proximité des plans d'eau sur la base d'évaluations écotoxicologiques réalistes des risques.

Mots-clés : métaux lourds / pollution de l'eau / munition / plomb / Daphnia magna

\footnotetext{
*Corresponding author: geist@wzw.tum.de

${ }^{a}$ These authors contributed equally.
} 


\section{Introduction}

Metal contamination of aquatic systems and the resulting impacts on biota have been recognized as a subject of great concern for many decades. Especially lead was identified as harmful to both the environment and human health due to its environmental persistence and accumulation potential in tissues of organisms (e.g. Spehar et al., 1978; Vinodhini and Narayanan, 2008). Whilst the emission of heavy metals into the environment has substantially decreased in industrialized states (Nriagu, 1996) due to the elimination of major emission sources (e.g. the ban of leaded gasoline), the relative importance of other, less well-known sources has increased. This also applies to introductions of metals by hunting activities, which can be a major entrance pathway of lead into aquatic ecosystems by the use of lead-based shotgun ammunition (Jørgensen and Willems, 1987; Ma, 1989). Many studies demonstrated lead poisoning of waterfowl caused by intake of spent lead shot, which can remain at the bottom of the water body (e.g. Irby et al., 1967; Locke et al., 1967; Grandy et al., 1968; Kelly et al., 1998; Mateo et al., 2007). Moreover, raptors and scavengers are also prone to lead poisoning due to the digestion of carcasses of animals shot with lead-based ammunition (Pain and Amiardtriquet, 1993; Kenntner et al., 2001; Müller et al., 2007; Krone et al., 2009).

As a consequence of these findings, some countries already prohibited the use of lead-based shot for waterfowl hunting several years ago (e.g. USA, Canada, Norway). After a public consultation concerning the ban of lead-based shot, the European Chemicals Agency (ECHA) is preparing a restriction proposal for the ban of lead shot in wetlands to prevent waterfowl from poisoning after the ingestion of dispersed lead pellets (ECHA, 2017). On the other hand, possible adverse effects to the environment from alternative materials like copper, zinc, iron, bismuth or tungsten have not yet been sufficiently tested, hampering management recommendations on the best possible alternatives. Thomas and Guitart (2003) already argued for the implementation of a mandatory toxicity screening (like the US Protocol according to USFWS (1997)) of all substitute shots that are commercially available in the EU. Without a screening of all alternatives there would still be several shot types on the European market that are already known to be highly toxic to wildlife and the environment. One example is the documented toxicity of zinc shot to avian wildlife (Levengood et al., 1999; Levengood et al., 2000) challenging the adequacy of this alternative metal.

In addition to harmful effects as a result of direct metal ingestion, acute toxic effects of dissolved heavy metals in aquatic systems (i.e. via aqueous exposures) have already been demonstrated in a variety of organisms. This was for example demonstrated for larvae of the white sturgeon Acipenser transmontanus (Vardy et al., 2014), the ostracod Stenocypris major (Shuhaimi-Othman et al., 2011) and the branchiopod Daphnia magna (Khangarot and Ray, 1989). Moreover, dissolved copper was also shown to impair reproduction and growth of the fathead minnow Pimephales promelas (Mount and Stephan, 1969), and alter gene expression patterns in delta smelt Hypomesus transpacificus (Connon et al., 2011). Likewise, dissolved zinc was demonstrated to inhibit the growth of grass carp Ctenopharyngodon idella (Chen et al., 2016).
Thus, some new and alternative materials to lead ammunition from European manufacturers, which are mostly used for hunting waterfowl and ultimately end up in aquatic systems, might also pose a risk to the aquatic biota. However, information on metal leaching behavior of spent shot and possible resulting impacts on aquatic organisms are not available yet. This is especially crucial, as the use of different metal alloys for alternative shot materials (Thomas, 2016) might result in different leaching behavior compared to the ion release of pure metals. Thus, risk assessments based on known dissolved-metal toxicity are potentially insufficient and might not reflect real circumstances. Additional leaching tests are required to investigate ecotoxicological effects of different shot materials under specific conditions.

Therefore, this study was intended to provide first insights into metal leaching behavior of experimentally spent gameshot in a controlled freshwater environment, and to connect this information with resulting toxic effects on an important aquatic model organism with high relevance for pelagic food web integrity. We investigated the leaching behavior of (i) two conventional lead-based shots and (ii) six alternative shots made of bismuth, copper, steel, tungsten or zinc as well as (iii) a coated lead-based prototype at four exposure time points. Subsequently, the acute D. magna $48 \mathrm{~h}$ toxicity test was utilized to assess possible ecotoxicological effects of the resulting leachates. We hypothesized that the main component, based on manufacturer's data, is the one which is the dominantly released metal during the exposure of game shot to freshwater. Furthermore, due to the common assumption of lead shot posing a high threat to the environment, the exposure of alternative shot was hypothesized to not result in increased immobilization rates in D. magna compared to lead shot. The results of this study are intended to guide management and legal decisions on the future use of shot ammunition near waterbodies.

\section{Material and methods}

\subsection{Investigated shots}

Nine types of shotgun ammunition (Tab. 1) were selected considering a broad representation of different shot materials available in the EU: lead $(\mathrm{Pb})$, iron $(\mathrm{Fe})$, copper $(\mathrm{Cu})$, zinc $(\mathrm{Zn})$, tungsten $(\mathrm{W})$ and bismuth (Bi). Similar sizes were chosen (size number \#2) with the exception of two shots (Fiocchi PL 34 and Eley Bismuth Alphamax) which were only available with a smaller diameter (Tab. 1). The selection of shot ammunition was conducted in close collaboration with the Bavarian Hunting Association (BJV) to consider the most relevant ammunition types and sizes. RUAG Ammotec $\mathrm{GmbH}$ disassembled the shot pellets from the cartridges and provided a galvanic tin-coated prototype with a lead core for an investigation of the manipulated $\mathrm{Pb}$-leaching through a galvanic lamination on $\mathrm{Pb}$ shot. Unexpectedly, the cartridges of FOB Sweet Copper contained a small percentage of copper coated lead shot pellets. In order to standardize the testing conditions, only the pure copper shots were used in this case for subsequent investigations.

\subsection{Metal leaching behavior}

Since this study should enable a first relative comparison of the leaching behavior and ecotoxicological effects between the 
Table 1. Overview of the different types of game shot, the respective size number (\#2: $3.75 \mathrm{~mm}$ diameter; $\# 3$ : $3.5 \mathrm{~mm}$ diameter) and the main element according to the product specification.

\begin{tabular}{llll}
\hline Shot type & Size number & Main element & Source \\
\hline Fiocchi PL 34 (PL 34) & $\# 3$ & $\mathrm{~Pb}$ & www.fiocchiuk.com \\
RWS Silver Selection (Silver) & $\# 2$ & $\mathrm{~Pb}$ & www.rws-munition.de \\
Coated prototype & $\# 2$ & $\mathrm{~Pb}$ & RUAG Ammotec GmbH \\
Rottweil Steel Game (Steel Game) & $\# 2$ & $\mathrm{Fe}$ & www.rws-munition.de \\
Winchester Blind Side (Blind Side) & $\# 2$ & $\mathrm{Fe}$ & www.winchester.com \\
Eley Bismuth Alphamax (Alphamax) & $\# 3$ & $\mathrm{Bi}$ & www.eleyhawkltd.com \\
FOB Sweet Copper (Sweet Copper) & $\# 2$ & $\mathrm{Cu}$ & www.cartouchesfob.fr \\
Rottweil Ultimate (Ultimate) & $\# 2$ & $\mathrm{~W}$ & www.rws-munition.de \\
SK Hubertus Zink (Hubertus) & $\# 2$ & $\mathrm{Zn}$ & www.jagdgewehr.de \\
\hline
\end{tabular}

different materials, we used a preferably simple experimental set-up by focusing on an aqueous exposure, excluding effects of different substrates and redox conditions.

Shot pellets were exposed in a defined freshwater environment, suitable for the Daphnia test (water hardness: $250 \mathrm{mg} / \mathrm{L} \mathrm{CaCO}_{3}$ ) consisting of $333 \mathrm{mg}$ synthetic sea salt, $2.3 \mathrm{~mL} \mathrm{CaCl}$-solution $(0.8 \mathrm{~mol} / \mathrm{L}), 2.2 \mathrm{~mL} \mathrm{NaHCO}$-solution $(0.3 \mathrm{~mol} / \mathrm{L})$ and $0.1 \mathrm{~mL} \mathrm{SeO}$-solution $(0.13 \mathrm{~mol} / \mathrm{L})$ dissolved in $1 \mathrm{~L}$ deionized water (ADaM; Klüttgen et al., 1994). Two pellets of each respective shot type were exposed in each of 12 (3 replicates for 4 different exposure times) medical urine cups (Uritop, Frohnhäuser) filled with $100 \mathrm{~mL}$ ADaM. In contrast to existing guidelines like the OECD (2001) that stipulate big volumes of a pre-defined exposure medium, we adjusted exposure volumes to $100 \mathrm{~mL}$ to ensure more homogenous exposure conditions. Since cartridges of this calibre contain up to 200 pellets, the pellet-water ratio likely mimics a highexposure scenario as e.g. occurring in shallow water conditions. The cups were closed and the solutions were aerated with pre-cleaned, compressed and water-saturated air to promote aerobic conditions and a circulation in the medium (Fig. 1). Following the OECD (2001) guidelines, we decided to choose a short term $(24 \mathrm{~h})$ and long term time point (a maximum of $22 \mathrm{~d}$ was technically feasible) as well as two intermediate time points $(8 \mathrm{~d}, 15 \mathrm{~d})$. At exposure termination three cups per each type of shot were removed and samples were completely filtered $(0.45 \mu \mathrm{m})$ for subsequent metal analysis and D. magna immobilization tests.

\subsection{Metal analysis}

After filtering, aliquots of $12 \mathrm{~mL}$ were taken from each water sample for metal analysis by inductively coupled plasma atomic emission spectrometry (ICP-AES; Genesis, Spectro Kleve). All eluates were analyzed for the concentration of dissolved $\mathrm{As}, \mathrm{Cr}, \mathrm{Cu}, \mathrm{Fe}, \mathrm{Mn}, \mathrm{Ni}, \mathrm{Pb}, \mathrm{Sb}, \mathrm{Sn}$ and $\mathrm{Zn}$ and corrected for the background concentration of ADaM. Samples of the shot types Alphamax and Ultimate were additionally investigated for their content of dissolved $\mathrm{Bi}$ and $\mathrm{W}$ concentrations in the same way. The determination of detection limits and limits of quantification (LOQ) was conducted by measuring 10 blank values. According to DIN 32645: 2008-11 (DIN, 2008) limits were calculated by adding the mean concentration of blank values and the threefold respectively

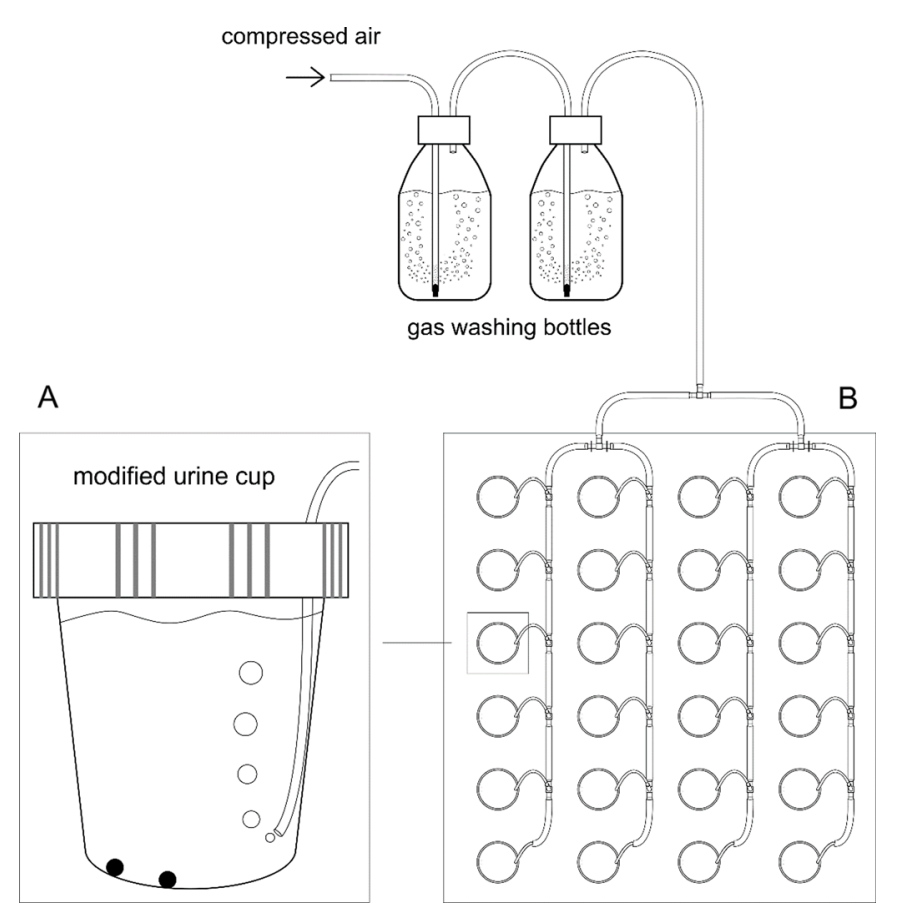

Fig. 1. Experimental setup of the metal leaching test. (A) Single exposure unit and (B) arrangement of the exposure units during the experiment (two shot types tested simultaneously).

tenfold standard deviation for detection limit respectively limit of quantification. For better comparison of the metal leaching behavior all concentrations are given in $\mu \mathrm{mol} / \mathrm{L}$.

\subsection{Daphnia magna immobilization test}

A culture of the D. magna clone K34J has been maintained at the Aquatic Systems Biology Unit at the Technical University of Munich in Freising, Germany, for more than 7 years. Daphnia were cultured in $920 \mathrm{~mL}$ beakers filled with the same water that was used for the shot leaching experiment $(\mathrm{ADaM})$ at a density of 10 Daphnia/L. Adult Daphnia were transferred into new beakers containing new water 3 times a week. At the same time the green alga Scenedesmus obliquus was provided ad libitum as food and juveniles were removed. In order to avoid overaging of Daphnia mothers, new cultures 
Table 2. Mean effect concentrations ( $\mathrm{EC}_{50}$ values, $48 \mathrm{~h}$ immobilization; $\mu \mathrm{mol} / \mathrm{L}$ ) of dissolved metals on $D$. magna at water hardness $240 \mathrm{mg} / \mathrm{L}$ $\mathrm{CaCO}_{3}$ (Khangarot and Ray, 1989). $\mathrm{EC}_{50}$ for $\mathrm{Bi}$ at water hardness $72 \mathrm{mg} / \mathrm{L} \mathrm{CaCO} 3$ (Okamoto et al., 2015).

\begin{tabular}{|c|c|c|c|c|c|}
\hline As & $\mathrm{Bi}$ & $\mathrm{Cr}$ & $\mathrm{Cu}$ & $\mathrm{Fe}$ & $\mathrm{Mn}$ \\
\hline 83 & $>62$ & 34 & 1.46 & 129 & 151 \\
\hline $\mathrm{Ni}$ & $\mathrm{Pb}$ & $\mathrm{Sb}$ & $\mathrm{Sn}$ & W & $\mathrm{Zn}$ \\
\hline 124 & 17 & 3478 & 182 & 486 & 8.57 \\
\hline
\end{tabular}

were started every third week using juveniles from the precursor culture. Thus, test-daphnids were collected from different broods during the first three weeks of reproduction. Cultures were placed in a climate chamber set to $20^{\circ} \mathrm{C}$ $\left(19.9 \pm 0.2^{\circ} \mathrm{C}\right.$; mean $\pm \mathrm{SD}$ of reference measurements $)$ and a light:dark cycle of $16: 8 \mathrm{~h}$. The toxicity tests were conducted according to the EN ISO 6341:2012 guideline (DIN, 2013). Two or three shot types were investigated simultaneously resulting in a total test period of 16 weeks. For the toxicity tests the three filtered water samples from each shot exposure time were pooled and 6 beakers $(100 \mathrm{~mL})$ were filled with $40 \mathrm{~mL}$ of the test solution. Thus, water conditions were equal in the replicates. The remaining solution was used for $\mathrm{pH}$ measurement. Another six beakers filled with ADaM served as control. Five juvenile daphnids ( $<24 \mathrm{~h}$, not first brood) were transferred into each beaker. Daphnids were not fed during the test. The test was terminated after $48 \mathrm{~h}$ and the number of immobile daphnids was counted. Subsequently, dissolved oxygen and $\mathrm{pH}$ were measured. Tests were conducted under the same temperature and light conditions as the culturing.

\subsection{Statistical analyses}

Dissolved metal concentrations where compared with literature data (Khangarot and Ray, 1989; Okamoto et al., 2015) on metal toxicity to D. magna (48 h immobilization) at comparable water hardness to identify exceedances of mean effect concentrations ( $\mathrm{EC}_{50}$-values, Tab. 2). Normality of data was tested using Kolmogorov-Smirnov's test. As data were not normally distributed, Kruskal-Wallis tests were used to test for differences in Daphnia immobilization among treatments. Pairwise Mann-Whitney-U tests with subsequent Bonferroni adjustment were applied between shot treatments and the control in case of significance $(P<0.05)$.

\section{Results}

\subsection{Metal analysis}

The highest molar metal concentrations were measured in water samples of the steel shot Blind Side and Hubertus zinc shot with values up to $34.88 \mu \mathrm{mol} \mathrm{Zn} / \mathrm{L}$ and $41.12 \mu \mathrm{mol} \mathrm{Zn} / \mathrm{L}$, respectively, exceeding the $\mathrm{EC}_{50}$ (D. magna immobilization) of zinc at most time-points (Tabs. 2 and 3). For the alternative shot type Sweet Copper, leaching of its main element at concentrations from 0.79 to $4.22 \mu \mathrm{mol} \mathrm{Cu} / \mathrm{L}$ (exceeding the $\mathrm{EC}_{50}$ from day 8 on) were found, similar to the concentrations from PL 34 with detected $\mathrm{Pb}$-concentrations of up to $2.35 \mu \mathrm{mol} / \mathrm{L}$ (below $\mathrm{EC}_{50}$ ). The shot Steel Game released manganese resulting in a concentration up to $0.49 \mu \mathrm{mol} / \mathrm{L}$. The chemical analysis of the shot types Alphamax, Ultimate and the coated prototype either only resulted in leachates with metal concentrations below the limit of quantification or no element exceeded the detection limit. Furthermore, some shot types released different than the expected metal ions (Alphamax: $\mathrm{Sn}, \mathrm{Ni}, \mathrm{Pb}$; Ultimate: $\mathrm{As}, \mathrm{Ni}$, Sn; Blind Side: Zn; Silver: Ni) likely resulting from coatings or alloy components. For instance, leaching of the $\mathrm{Pb}$-based shot type Silver resulted in concentration ranges of $0.49 \mu \mathrm{mol} / \mathrm{L}$ to $1.70 \mu \mathrm{mol} / \mathrm{L}$ for Ni. Only Hubertus, PL 34 and Sweet Copper released the respective main compounds as expected from their declaration. The only leached metal of the coated lead prototype was $\mathrm{Sn}$ with a concentration below the LOQ, which was only detected after 8 days. For detailed information of all measured metal concentrations see Table S1, supplementary data.

\subsection{Daphnia magna toxicity test}

Immobilization of D. magna was significantly increased as compared to the control in test solutions of three shot types at every time point (Fig. 2): Sweet Copper (Mann-Whitney-U: $P=0.016$ (1d), $P=0.008$ (8d), $P=0.012$ (15d), $P=0.006$ (22d)), Hubertus (Mann-Whitney-U: $P=0.012$ (1d), $P=0.006$ (8d), $P=0.006$ (15d), $P=0.006(22 \mathrm{~d}))$ and Blind Side (MannWhitney-U: $P=0.006$ (1d), $P=0.006$ (8d), $P=0.004$ (15d), $P=0.004$ (22d)). No other shot-leachate caused a significantly increased immobilization at any shot-exposure length. Immobilization rates caused by leachates from Sweet Copper and Hubertus were consistently high (81-100\%) at every time-point. In contrast, immobilization rates caused by leachates from Blind Side increased by $61 \%$ from day 1 to day 15 , and decreased by $18 \%$ at day 22. For the lead shot PL 34 leachate, there was an increase of Daphnia immobilization at day 1 (not significant), with a high variation caused by a mortality of $100 \%$ in one testbeaker (SD: 39\%). At the following time points, immobilization rates were clearly reduced by $58 \%$ (days 8 and 15 ) and $90 \%$ (day 22 ). Mean control mortality was $<10 \%$ in all tests (range: $0-8 \%$ ). Dissolved oxygen was in the range of $7.2-10.0 \mathrm{mg} / \mathrm{L}$ at the end of the test in all test beakers. $\mathrm{pH}$-values did not change by more than 0.6 units during the test and ranged from 7.3 to 8.0 and 7.5 to 8.1 at test beginning and end, respectively, over all treatments.

\section{Discussion}

This study provides first information on metal leaching behavior from different types of gameshot in freshwater systems directly linked with resulting ecotoxicological impacts. Whilst the results clearly suggest that some 
Table 3. Molar concentrations $[\mu \mathrm{mol} / \mathrm{L}]$ and standard deviations of the mainly released metal ions after $1,8,15$ and 22 days of shot exposure in $\mathrm{ADaM}$. Bold numbers indicate exceedance of D. magna $48 \mathrm{~h}$ immobilization $\mathrm{EC}_{50}$-values of respective metals (according to Tab. 2).

\begin{tabular}{|c|c|c|c|c|}
\hline & \multicolumn{4}{|c|}{ Exposure day } \\
\hline & 1 & 8 & 15 & 22 \\
\hline \multirow[b]{2}{*}{ PL 34} & $\mathrm{~Pb}$ & $\mathrm{~Pb}$ & $\mathrm{~Pb}$ & $\mathrm{~Pb}$ \\
\hline & $2.35 \pm 0.33$ & $1.27 \pm 0.19$ & $<\mathrm{LOQ}^{\mathrm{a}}$ & $1.16 \pm 0.13$ \\
\hline \multirow[b]{2}{*}{ Silver } & $\mathrm{Ni}$ & $\mathrm{Ni}$ & $\mathrm{Ni}$ & $\mathrm{Ni}$ \\
\hline & $0.49 \pm 0.10$ & $0.69 \pm 0.24$ & $1.70 \pm 0.39$ & $0.97 \pm 0.07$ \\
\hline Coated prototype & n.d. ${ }^{b}$ & $\begin{array}{l}\text { Sn } \\
<\text { LOQ }\end{array}$ & n.d. & n.d. \\
\hline \multirow{2}{*}{ Steel Game } & $\mathrm{Mn}$ & $\mathrm{Mn}$ & $\mathrm{Mn}$ & $\mathrm{Mn}$ \\
\hline & $0.12 \pm 0.01$ & $0.49 \pm 0.05$ & $0.39 \pm 0.25$ & $0.41 \pm 0.11$ \\
\hline \multirow{2}{*}{ Blind Side } & $\mathrm{Zn}$ & $\mathrm{Zn}$ & $\mathrm{Zn}$ & $\mathrm{Zn}$ \\
\hline & $6.13 \pm 1.36$ & $20.65 \pm 2.92$ & $34.88 \pm 1.10$ & $34.53 \pm 3.38$ \\
\hline \multirow[b]{2}{*}{ Alphamax } & $\mathrm{Sn}$ & $\mathrm{Bi}, \mathrm{Ni}$ & $\mathrm{Fe}, \mathrm{Pb}$ & $\mathrm{Pb}, \mathrm{Sn}$ \\
\hline & $<\mathrm{LOQ}$ & $<\mathrm{LOQ}$ & $<\mathrm{LOQ}$ & $<\mathrm{LOQ}$ \\
\hline \multirow[b]{2}{*}{ Sweet Copper } & $\mathrm{Cu}$ & $\mathrm{Cu}$ & $\mathrm{Cu}$ & $\mathrm{Cu}$ \\
\hline & $0.79 \pm 0.18$ & $\mathbf{3 . 0 3} \pm \mathbf{0 . 2 9}$ & $4.22 \pm 0.90$ & $4.00 \pm 1.11$ \\
\hline \multirow{2}{*}{ Ultimate } & As & $\mathrm{Ni}$ & $\mathrm{Ni}$ & $\mathrm{Mn}, \mathrm{Sn}$ \\
\hline & $<\mathrm{LOQ}$ & $<\mathrm{LOQ}$ & $<\mathrm{LOQ}$ & $<\mathrm{LOQ}$ \\
\hline \multirow[b]{2}{*}{ Hubertus } & $\mathrm{Zn}$ & $\mathrm{Zn}$ & $\mathrm{Zn}$ & $\mathrm{Zn}$ \\
\hline & $26.46 \pm 10.86$ & $41.12 \pm 5.70$ & $34.42 \pm 0.62$ & $26.54 \pm 1.17$ \\
\hline
\end{tabular}

a $\mathrm{LOQ}=$ limit of quantification

$\mathrm{b}$ n.d. $=$ not detected.

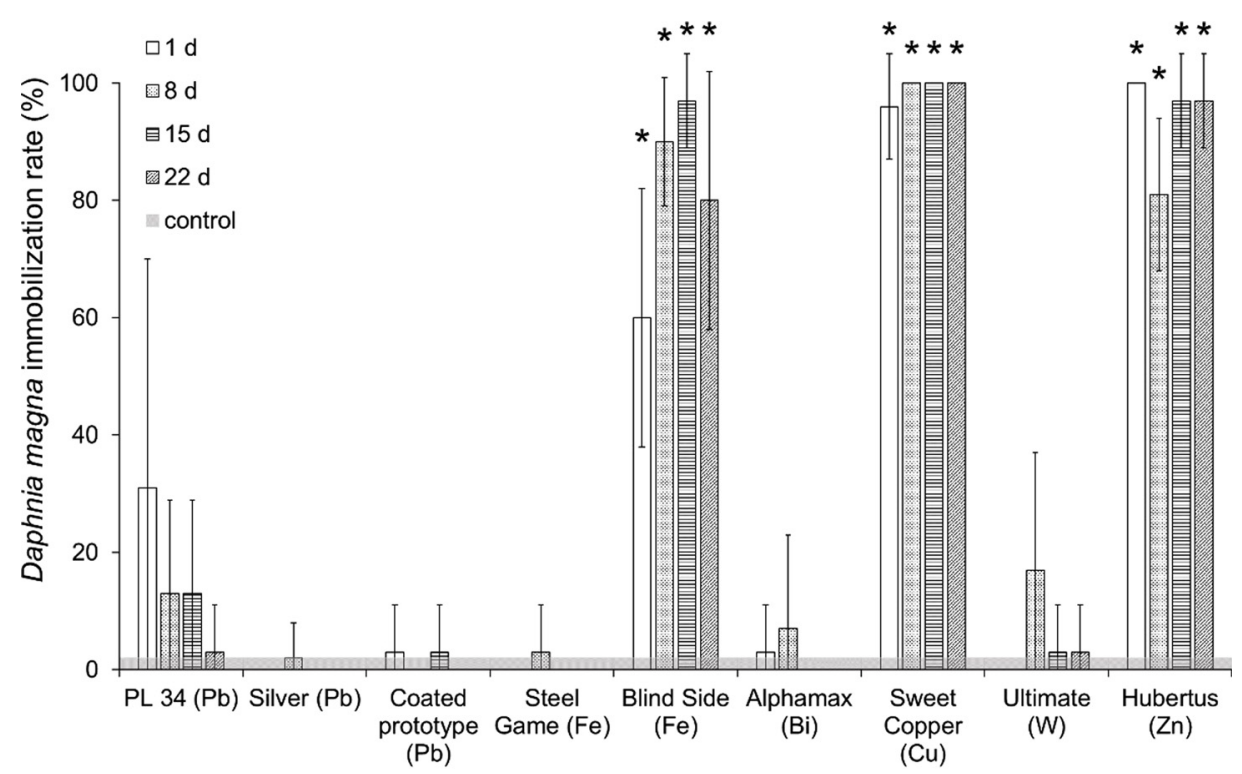

Type of game shot

Fig. 2. Mean immobilization rates and standard deviations in the $48 \mathrm{~h}$ acute toxicity test with $D$. magna after $1,8,15$ and 22 days of shot exposure. Control resembles mean immobilization rate of untreated Daphnia over the whole test phase. Asterisks indicate significant differences $(P<0.05)$ to the control. The declared main component of the shot is given in brackets.

alternative gameshots pose a higher ecotoxicological risk for aquatic organisms than classical $\mathrm{Pb}$-based ammunition, further research is needed to assess the actual exposure risk in the wild, including a range of different taxa. In addition, abiotic factors like $\mathrm{pH}$, water hardness or organic carbon can substantially change both metal leaching behavior as well as toxicities of the leachates, requiring further testing under likely environmental conditions. Thus, the present study should be primarily seen as a proof-of-concept that lead-free gameshot can release metals of ecotoxicological concern. 
Leaching of copper and zinc resulted in significantly increased immobilization rates up to $100 \%$ of D. magna, which was already observed after $24 \mathrm{~h}$ of shot exposure. In contrast to the common assumption that lead would be the most toxic and problematic metal in game shot, none of the tested lead shots significantly increased immobilization within this relative comparison at any time point. Instead, especially the leaching of copper and zinc from new alternative shot types suggests severe impacts on aquatic biota as demonstrated in D. magna which is a keystone species of freshwater systems. Measured concentrations of copper (up to $4.22 \mu \mathrm{mol} / \mathrm{L}$ ) and zinc (up to $41.12 \mu \mathrm{mol} / \mathrm{L}$ ) indeed mostly exceeded $48 \mathrm{~h}$ D. magna immobilization $\mathrm{EC}_{50}$ values found in the literature (Khangarot and Ray, 1989; Tab. 2) in treatments with significantly increased Daphnia immobilization. These findings are in line with various studies demonstrating a high sensitivity of aquatic organisms like fungi, green algae, dragonflies and snails exposed to these metals at comparable or even lower concentrations (Knauer et al., 1997; Tollett et al., 2009; Azevedo and Cássio, 2010; Khangarot and Das, 2010). However, in our study, mean immobilization rates of daphnids were often below $100 \%$, which might be due to the formation of non-bioavailable compounds. A clear determination of metal-speciation was not possible in our study because of using the ICP-AES Method. In contrast, even the highest lead concentrations did not significantly increase Daphnia immobilization in the present study, as the measured concentrations remained below the respective $\mathrm{EC}_{50}$ values (Khangarot and Ray, 1989), possibly due to the formation of insoluble oxide compounds. However, lead concentrations exceeded the $7 \mathrm{~d}$ $\mathrm{LC}_{50}$ value $(0.54 \mu \mathrm{mol} / \mathrm{L})$ determined with the amphipod Hyalella azteca (Borgmann et al., 2005) indicating potential acute impacts of dissolved lead from shots on other aquatic organisms. As sensitivities of aquatic organisms can substantially vary, e.g. depending on route of uptake or detoxification processes, possible adverse effects of the remaining metals at measured concentrations for other organisms than Daphnia cannot be excluded. Moreover, chronic effects of leached metals at these concentrations are likely to occur, especially due to the bioaccumulation potential of heavy metals like lead, as aquatic organisms are not able to actively regulate metal concentrations in tissues (McGeer et al., 2003).

Depending on the shot type, high amounts of metals were already leached during the exposure within the first $24 \mathrm{~h}$ (Tab. 3 ). Surprisingly, the metal, which was mostly released into the water, was not necessarily the declared main component of the shot, as demonstrated in 6 out of 9 types of shot in the present study. This might be caused by an additional coating of the shot surface as observed for the steel shot Blind Side where high concentrations of zinc were detected in the water samples. Furthermore the Pb-shot Silver Selection is obviously coated with nickel. Another reason for the leaching of additional metals can be the use of alloys, as in the case of Steel Game, where $\mathrm{Mn}$ is an obvious alloy component of this iron-based shot. These findings are surprising on first glance, but they also match previous results of the leaching behavior of rifle bullets in different percolation tests (Schwarz et al., 2015). Similarly, Thomas (2016) identified different possible alloying elements in tungsten-based shot (e.g. nickel) affecting the leaching behavior. Therefore, the ecotoxicological risk assessment of game shot should not be limited to the toxicity of its declared main component or metal, but rather be based on its leaching behavior under realistic and pre-defined environmental conditions. Concerning coating techniques, a leaching of lead could be inhibited for undeformed shot in aquatic systems through a special lamination demonstrated by the coated prototype. Because the damage of such a "shot-jacket" cannot be excluded, these results need to be verified in further investigations testing the deformation of coated shot pellets during firing action. However, the poisoning of waterfowl, raptors and scavengers following the digestion of lead ammunition (Irby et al., 1967; Locke et al., 1967; Grandy et al., 1968; Kelly et al., 1998; Kenntner et al., 2001; Mateo et al., 2007; Müller et al., 2007; Krone et al., 2009) is attributed to the release of $\mathrm{Pb}$ ions as a result of the grinding activity and the acidic environment of the gizzard (Scheuhammer and Norris, 1996). Thus, an intoxication of birds following the digestion of new coated lead shots cannot be excluded and should be investigated in the near future.

In conclusion, the results of this study clearly indicate that some European game shot substitutes, which can accumulate in freshwater systems, are an insufficiently considered ecotoxicological risk. According to our results, shot types leaching copper or zinc pose a high risk to the aquatic biocenosis, whereas game shot made of tungsten, bismuth or steel without a toxic coating might be alternatives that are less harmful to aquatic wildlife. The observed discrepancies between the expected and observed leaching behavior of different game shot and the ecotoxicological effects on $D$. magna should be verified also considering other species and more realistic environmental conditions. In particular, metal leaching and speciation and thus bioavailability is influenced by physicochemical parameters of the water matrix (e.g. acid/ calcareous water) which have to be considered in further investigations concerning the fate of game shot in natural waters. Moreover, investigations of possible chronic effects on aquatic organisms are required for an adequate assessment of the environmental risk of gameshot in freshwater systems. Consequently, the ban of lead shot in order to protect humans and other vertebrate species like waterfowl as currently discussed on European Union level has to be critically evaluated in light of available substitutes which must not be more hazardous to aquatic systems. Based on the findings of this study, manufacturer statements that their ammunition is "lead-free" or represents a proper and environmentally safe lead substitute clearly not mean that it is devoid of toxic effects. Hence, these aspects have to be pursued by introducing rigorous legal shot testing criteria at the national and European Union levels. Specifically, a better consideration of the toxicity for aquatic key species is necessary in addition to the wellknown toxicity to avian wildlife. Management of aquatic ecosystems should restrict the use of critically assessed shot substitutes that contain zinc, copper and zinc coatings on a legal basis. Moreover, licensed use of shot types near water bodies should be based on a thorough ecotoxicological risk assessment that ideally comprises both the already well-known risk to avian species, and the less well documented risk to aquatic or terrestrial species.

Acknowledgements. We are grateful for the support by RUAG Ammotec $\mathrm{GmbH}$ which disassembled all cartridges and provided a coated prototype of shot for the investigations. We 
also acknowledge support by the Bavarian Hunting Association (BJV) in selecting different types of game shot. We thank P. Luginger for technical assistance in the D. magna tests. The study was funded by the hunting licence fee of the Bavarian State Ministry for Nutrition, Agriculture and Forestry (StMELF). We are grateful to three anonymous reviewers for their helpful comments.

\section{References}

Azevedo MM, Cassio F. 2010. Effects of metals on growth and sporulation of aquatic fungi. Drug Chem Toxicol 33: 269-278.

Borgmann U, Couillard Y, Doyle P, Dixon DG. 2005. Toxicity of sixty-three metals and metalloids to Hyalella azteca at two levels of water hardness. Environ Toxicol Chem 24: 641-652.

Chen WY, Chen TY, Hsieh NH, Ju YT. 2016. Site-specific water quality criteria for lethal/sublethal protection of freshwater fish exposed to zinc in southern Taiwan. Chemosphere 159: 412-419.

Connon RE, Beggel S, D'Abronzo LS, Geist JP, Pfeiff J, Loguinov AV, Vulpe CD, Werner I. 2011. Linking molecular biomarkers with higher level condition indicators to identify effects of copper exposures on the endangered delta smelt (Hypomesus transpacificus). Environ Toxicol Chem 30: 290-300.

DIN 2008. Chemical analysis - decision limit, detection limit and determination limit under repeatability conditions - Terms, methods, evaluation. DIN 32645:2008-11, Berlin: Deutsches Institut für Normung, Beuth Verlag GmbH.

DIN 2013. Water quality - determination of the inhibition of the mobility of Daphnia magna Straus (Cladocera, Crustacea) - Acute toxicity test (ISO 6341:2012); German version EN ISO 6341:2012. Berlin: Deutsches Institut für Normung, Beuth Verlag $\mathrm{GmbH}$.

European Chemicals Agency (ECHA). 2017. ECHA proposes a restriction on lead and its compounds in gunshot. https://echa. europa.eu/documents/10162/d7fb96cf-7956-74063568-399ca20151e0.

Grandy JW, Locke LN, Bagley GE. 1968. Relative toxicity of lead and five proposed substitute shot types to pen-reared mallards. $J$ Wildl Manag 32: 483-488.

Irby HD, Locke LN, Bagley GE. 1967. Relative toxicity of lead and selected substitute shot types to game farm mallards. J Wildl Manag 31: $253-257$.

Jørgensen SS, Willems M. 1987. The fate of lead in soils: the transformation of lead pellets in shooting-range soils. Ambio 16: $11-15$.

Kelly ME, Fitzgerald SD, Aulerich RJ, Balander RJ, Powell DC, Stickle RL, Stevens W, Cray C, Tempelman RJ, Bursian SJ. 1998. Acute effects of lead, steel, tungsten-iron, and tungsten-polymer shot administered to game-farm mallards. J Wildl Dis 34: 673-687.

Kenntner N, Tataruch F, Krone O. 2001. Heavy metals in soft tissue of white-tailed eagles found dead or moribund in Germany and Austria from 1993 to 2000. Environ Toxicol Chem 20: 1831-1837.

Khangarot BS, Das S. 2010. Effects of copper on the egg development and hatching of a freshwater pulmonate snail Lymnaea luteola L. $J$ Hazard Mater 179: 665-675.

Khangarot BS, Ray PK. 1989. Investigation of correlation between physicochemical properties of metals and their toxicity to the water flea Daphnia magna Straus. Ecotoxicol Environ Saf 18: 109-120.

Klüttgen B, Dülmer U, Engels M, Ratte HT. 1994. ADaM, an artificial freshwater for the culture of zooplankton. Water Res 28: 743-746.

Knauer K, Behra R, Sigg L. 1997. Effects of free $\mathrm{Cu} 2+$ and $\mathrm{Zn} 2+$ ions on growth and metal accumulation in freshwater algae. Environ Toxicol Chem 16: 220-229.
Krone O, Kenntner N, Tataruch F. 2009. Gefährdungsursachen des Seeadlers (Haliaeetus albicilla L 1758). Denisia 27: 139-146.

Levengood JM, Sanderson GC, Anderson WL, Foley GL, Skowron LM, Brown PW, Seets JW. 1999. Acute toxicity of ingested zinc shot to game-farm mallards. Ill Nat Hist Surv Bull 36: 1-36.

Levengood JM, Sanderson GC, Anderson WL, Foley GL, Brown PW, Seets JW. 2000. Influence of diet on the hematology and serum biochemistry of zinc-intoxicated mallards. J Wildl Dis 36: 111-123.

Locke LN, Irby HD, Bagley GE. 1967. Histopathology of mallards dosed with lead and selected substitute shot. J Wildl Dis 3: 143 147.

Ma WC. 1989. Effect of soil pollution with metallic lead pellets on lead bioaccumulation and organ/body weight alterations in small mammals. Arch Environ Contam Toxicol 18: 617-622.

Mateo R, Green AJ, Lefranc H, Baos R, Figuerola J. 2007. Lead poisoning in wild birds from southern Spain: a comparative study of wetland areas and species affected, and trends over time. Ecotoxicol Environ Saf 66: 119-126.

McGeer JC, Brix KV, Skeaff JM, DeForest DK, Brigham SI, Adams WJ, Green A. 2003. Inverse relationship between bioconcentration factor and exposure concentration for metals: implications for hazard assessment of metals in the aquatic environment. Environ Toxicol Chem 22: 1017-1037.

Mount DI, Stephan CE. 1969. Chronic toxicity of copper to the fathead minnow (Pimephales promelas) in soft water. J Fish Res Board Can 26: 2449-2457.

Müller K, Altenkamp R, Brunnberg L. 2007. Morbidity of freeranging white-tailed sea eagles (Haliaeetus albicilla) in Germany. $J$ Avian Med Surg 21: 265-274.

Nriagu JO. 1996. A history of global metal pollution. Science 272: 223-224.

Okamoto A, Yamamuro M, Tatarazako N. 2015. Acute toxicity of 50 metals to Daphnia magna. J Appl Toxicol 35: 824-830.

Organization for Economic Cooperation and Development (OECD). 2001. Guidance document on transformation/dissolution of metals and metal compounds in aqueous media. OECD Series on Testing and Assessment, Number 29.

Pain DJ, Amiardtriquet C. 1993. Lead-poisoning of raptors in France and elsewhere. Ecotoxicol Environ Saf 25: 183-192.

Scheuhammer AM, Norris SL. 1996. The ecotoxicology of lead shot and lead fishing weights. Ecotoxicology 5: 279-295.

Schwarz D, Fäth J, Göttlein A. 2015. Development of a standardized test method for investigating the environmental solubility of metal ions from materials used in rifle bullets. Allg Forst Jagdztg 186: $175-187$.

Shuhaimi-Othman M, Yakub N, Ramle N-A, Abas A. 2011. Toxicity of metals to a freshwater ostracod: stenocypris major. $J$ Toxicol 2011.

Spehar RL, Anderson RL, Fiandt JT. 1978. Toxicity and bioaccumulation of cadmium and lead in aquatic invertebrates. Environ Pollut 15: 195-208.

Thomas VG. 2016. Elemental tungsten, tungsten-nickel alloys and shotgun ammunition: resolving issues of their relative toxicity. Eur $J$ Wildl Res 62: 1-9.

Thomas VG, Guitart R. 2003. Evaluating non-toxic substitutes for lead shot and fishing weights. Environ Policy Law 33: 150-154.

Tollett VD, Benvenutti EL, Deer LA, Rice TM. 2009. Differential toxicity to $\mathrm{Cd}, \mathrm{Pb}$, and $\mathrm{Cu}$ in dragonfly larvae (Insecta: odonata). Arch Environ Contam Toxicol 56: 77-84.

USFWS. 1997. Migratory bird hunting: revised test protocol for nontoxic approval procedures for shot and shot coating; 50 CFR Part 20; Department of the Interior. U.S. Fish and Wildlife Service. Washington, DC. Fed. Regist. 62: 63608-63615. 
J. Fäth et al.: Knowl. Manag. Aquat. Ecosyst. 2018, 419, 24

Vardy DW, Santore R, Ryan A, Giesy JP, Hecker M. 2014. Acute toxicity of copper, lead, cadmium, and zinc to early life stages of white sturgeon (Acipenser transmontanus) in laboratory and Columbia River water. Environ Sci Pollut Res 21: 8176-8187.
Vinodhini R, Narayanan M. 2008. Bioaccumulation of heavy metals in organs of fresh water fish Cyprinus carpio (Common carp). Int $J$ Environ Sci Technol 5: 179-182.

Cite this article as: Fäth J, Feiner M, Beggel S, Geist J, Göttlein A. 2018. Leaching behavior and ecotoxicological effects of different game shot materials in freshwater. Knowl. Manag. Aquat. Ecosyst., 418, 24. 